\title{
Skills development and structural change: Possibilities for and limitations of redressing structural racial inequalities in South Africa
}

\author{
Zelda Groener
}

\begin{abstract}
Improving structural racial equality for historically-disadvantaged Black South Africans, including low-skilled and unemployed adults and youths, is a pertinent challenge for the South African government during the ongoing transition from apartheid capitalism to post-apartheid capitalism. Within the framework of the National Skills Development Strategy (NSDS), the introduction of "learnerships" and "learning programmes", which include structured learning programmes, learnerships, apprenticeships and skills programmes, has had some impact. But emerging theoretical perspectives assert that apartheid structural racial inequalities persist and that structural reform is imperative. Opposing positions translate into two perspectives on social transition: either capitalism can be de-racialised, or capitalism in South Africa should be dismantled in order to de-racialise it. After a review of relevant literature and governmental documents, the author identifies five structural and pedagogical barriers as likely causes for low completion rates of skills development courses and concludes that structural reform needs more favourable political and economic conditions in order to be successful.
\end{abstract}

Keywords Adult education - Adult learning - Education and inequality - Skills development - Skills development and inequality - Learnerships • Learning programmes $\bullet$ Skills programmes $\bullet$ South Africa $\bullet$ Workplace learning

Resume Developpement des competences et reforme structurelle: possibilites et limites dans la reduction des inegalites raciales structurelles en Afrique du Sud Ameliorer l'egalite raciale structurelle pour les Sud-Africains noirs, traditionnellement defavorises et constitues en majorite de jeunes et d'adultes sans emploi et peu qualifies, est un important defi pour le gouvernement sud-africain actuel lors de cette transition du capitalisme de l'apartheid a un capitalisme post-apartheid. Dans le cadre de la strategie nationale de developpement des competences (NSDS), l'introduction de « groupes d'apprentissage » et de «programmes educatifs », comprenant des programmes d'apprentissage structure, l'apprentissage alterne en groupes, l'apprentissage professionnel et des programmes de qualification, a obtenu uncertain nombre de resultats. Mais les nouveaux points de vue theoriques affirment que les inegalites raciales inherentes aux structures de l'apartheid persistent et qu'une reforme structurelle est indispensable. Les positions opposees se traduisent par deux visions de la transition sociale : d'un cote le capitalisme peut etre deracialise, de l'autre le capitalisme sud-africain doit etre demantele pour etre deracialise. Apres un examen de la documentation afferente et des documents officiels, 
l'auteure identifie cinq obstacles structurels et pedagogiques comme les causes probables des faibles taux d'achevement obtenus par les cours de developpement des competences; elle conclut que pour reussir cette reforme structurelle, des conditions politiques et economiques plus favorables sont necessaires.

\section{Introduction}

Apartheid capitalist political economy created structural racial inequalities ${ }^{1}$ in all spheres of South African society. When the African National Congress government under Nelson Mandela came to power through the democratic elections in 1994, there was huge expectation among the historically-disadvantaged Black majority that apartheid inequalities would be eradicated, and that their lives would improve dramatically. As it turns out, several simultaneous converging and diverging transitions from apartheid capitalism to post-apartheid capitalism ${ }^{2}$ have ensued and, in the process, determined the possibilities and limitations for redressing inequalities in skills development and unemployment. While these transitions were rooted in a long struggle against apartheid and colonialism, they were also influenced by neo-liberal globalisation which has swept across the world since the 1980 s and created a need for skills development to facilitate transnational economic trade and exchanges. As a consequence, government and non-government institutions in many countries, including South Africa, have incorporated skills development into their educational policies and organisational arrangements. Thus skills development has emerged as a research interest in the study of comparative and international education policies and practices.

This article examines the question, "What possibilities and limitations have the transitions from apartheid capitalism to post-apartheid capitalism created for redressing structural racial inequalities in terms of skills development and unemployment?" In pursuit of this question, this article reviews relevant literature related to (1) international developments impacting political and economic change in South Africa; (2) political and economic change in South Africa; (3) skills development in South Africa; and (4) adult education in South Africa. In addition, this paper analyses important government policy documents related to skills development as well as the Department of Labour's annually-published National Skills Development Strategy: Implementation Report for the period 2001-2007. These reports capture the official statistics related to the South African government's implementation of skills development initiatives.

Theoretical perspectives on transitional political and economic changes serve as a framework in this paper for analysing the changes made by the South African government in terms of skills development and unemployment affecting Black, lowskilled and unemployed adults and youth. There is evidence that completion rates in

\footnotetext{
${ }^{1}$ The word "structural" in the term structural racial inequality refers to the idea that racial inequality was etched into all apartheid political and economic structures.

${ }_{2}^{2}$ In this article I use "post-apartheid capitalism" for easy reference to "capitalism in a post-apartheid society".
} 
these skills development programmes are still low today and that access to employment is limited. Arguing that racial inequality was etched into all apartheid political and economic structures, that barriers to skills development are structural, unemployment is structural and binding constraints on growth are structural, this paper asserts that structural transformation is required to redress structural racial inequalities. The article draws attention to the structure of the shrinking postapartheid capitalist economy which favours skilled labour over low-skilled labour and thus reproduces structural racial inequalities.

The paper concludes with a brief discussion of the debates about structural reform which could create political and economic conditions facilitating a change in the lives of Black, low-skilled and unemployed adults and youth.

\section{Transitions from apartheid capitalism to post-apartheid capitalism: possibilities and limitations for redressing apartheid inequalities}

Changing the lives of historically-disadvantaged Black South Africans, including Black, low-skilled and unemployed adults and youth, is a pertinent challenge for the South African government during the transition from the apartheid political economy. Over the past two decades several prominent academics and researchers have analysed this transition from different theoretical perspectives. These include Jonathan Michie and Vishnu Padayachee (1997) and Hein Marais (1998), who focus on the "political economy of transition"; Patrick Bond (2000), who analyses the post-1994 changes as "an elite transition"; Glenn Adler and Edward Webster (2001), who coined the term "double transition"; Zine Magubane (2004), who asked: "The revolution betrayed?" and Mashupye Maserumule (2011), who highlighted the importance of the "politics of transition".

I find these well-constructed and widely-cited perspectives pertinent to explain that in fact several transitions from apartheid capitalism have occurred, prompting the emergence of a post-apartheid capitalist society manifesting multiple polities such as elite rule, liberalism, neo-liberalism, liberal democracy and social democracy. The discussion below constitutes a framework for analysing the possibilities and limitations that the transitions from apartheid capitalism to post- apartheid capitalism have presented for redressing apartheid structural racial inequalities affecting Black, low-skilled and unemployed adults and youth in terms of skills development and employment.

\section{Apartheid capitalism and structural racial inequalities}

Debates which ensued in the 198 os about the characterisation of apartheid capitalism serve as a reminder of those features of the apartheid structures which must be changed in order to address structural racial inequalities. Two positions epitomised the opposite ends of the debates. At one end is the view that that there is a contradictory relationship between capitalism and racial domination (Saul and Gelb 
1986), while the other end argues that there is a contingent relationship between capitalism and racism (Wolpe 1988).

John S. Saul and Stephen Gelb describe the relationship between capitalism and racial domination as follows:

Thus for extended periods of time, the structure of racial domination has interpenetrated with and reinforced the structure of capitalist exploitation, producing what we have called a system of racial capitalism. Yet it need come as no surprise that this linkage between racial domination and capitalist exploitation is as potentially contradictory as, for long stretches of time in South Africa, it has been mutually reinforcing (Saul and Gelb 1986, p. 12).

By contrast, Harold Wolpe asserts that there is a "contingent relationship between capitalism and racism in South Africa",

that does not begin with a concept of racial capitalism, but nevertheless argues that the correlation of forces is such as to render it impossible for racial domination to become detached from capitalist relations. That is to say, while in principle capitalism and racialism are inseparable, the interpenetration which has occurred in practice and, most importantly, the vested interest of powerful groups and class forces in racial domination, are such as to make the de-racialisation of capitalism unrealisable (Wolpe 1988, p. 32).

These opposing positions translate into two perspectives on social transition: either capitalism can be de-racialised, or capitalism in South Africa should be dismantled in order to de-racialise it. Three kinds of transitions from apartheid capitalism to post-apartheid capitalism are considered in the next section: liberal, neo-liberal and social democratic.

\section{Elite transition to post-apartheid liberal capitalism}

The redress of apartheid racial inequalities may be the most critical challenge the democratic government should have considered when they came to power in 1994. Therefore the earliest critiques that focused on "elite transition" and incorporated a small number of Blacks seem relevant to understanding how the redress of apartheid racial inequalities that affected the lives of the historically-disadvantaged Black majority had receded from prominence. Webster and Adler (1999) argue that an elite transition, negotiated through social contracts and pacts, has circumvented a fundamental transformation. They contend that elite sectors, in their formation as "the elite", and the elite, capital and international capital in their respective alliances, have engineered the transition in their favour. They draw on the ideas of John Pilger (1998, p. 602), who captured the sense of disillusionment on the left when he lamented that an "historic compromise" between the African National Congress (ANC) and the apartheid government left economic power in the hands of the corporate White elite. All that has changed is the "inclusion of a small group of Blacks 
into this masonry" (Webster and Adler 1999, p. 347). In the same way, Bond describes post-1994 changes as "elite transition" that was secured through social contracts, pacts and compromises between the old White elite and the new Black elite, and between the newly-formed elite, capital and labour (Bond 2000).

Likewise, Solomon Johannes Terreblanche 3 argues that a Black and predominantly African elite is in control of government, while Guy Mhone claims that the Black elite is a "junior partner" and that White domination still reigns. Terreblanche explains, "The transformation of colonial capitalism into a first- world capitalist enclave has coincided with the introduction of a system of representative democracy which is effectively controlled by a Black, predominantly African elite" (Terreblanche 2002, p. 422). In support of his claim that the elite transition has been shaped by race, and referring to Mhone (2000), he asserts that, "Although the Black elite - both the bourgeoisie and petit bourgeoisie - has been adopted as a junior partner, the new system has retained its racist character: it still is a White-controlled enclave in a sea of Black poverty" (Terreblanche, p. 422). Building on Mhone, Terreblanche constructs a relationship between elite dominance, race and capitalism which he moulds into a political configuration and describes in the following way:

The politico-economic system that has replaced White political domination and colonial and racial capitalism is a liberal capitalist version of democratic capitalism, that can best be described as a system of African elite democracy cum capitalist enclavity. A new symbiotic relationship has been forged between the mainly White corporate elite and the Black governing elite in which the former is very much the senior partner and the latter very much the junior and dependent partner (ibid., p. 423).

Thus it can be argued that the emergence of a Black elite and its incorporation into the White corporate elite indicates that some features of apartheid capitalism have been de-racialised. However it is clear that these changes have benefited the Black elite itself, and have not necessarily increased the possibilities of redressing structural racial inequalities which could benefit the historically-disadvantaged Black majority.

\section{Transition to post-apartheid neo-liberal capitalism}

As the transitions took shape in one form or another, and it became apparent that the elite had opted for neo-liberalism, several thinkers developed theoretical perspectives on the transition from apartheid capitalism to post-apartheid neo-liberal capitalism (Webster and Adler 1999; Alexander 2003; Bond 2000, 2011a; Marais 1998, 2001, 2011). In reflecting on the transition to neo-liberalism, Bond traces the evolution of neo-liberalism in the ANC to "a neo-liberal faction within the ANC [which] had

\footnotetext{
${ }^{3}$ S. J. Terreblanche is among the analysts who have used both "representative democracy" and "liberal democratic capitalism" to characterise South Africa's democracy. The differences and similarities between these terms are not always clear. For the purposes of the discussion here, I have not attempted to delve into, or derive, the author's understandings of these different characterisations, but worked within his general assertion that through the 1994 election, democratic institutions, policies and procedures have been established.
} 
emerged around Thabo Mbeki, Trevor Manuel, Tito Mboweni, Alec Erwin, ultimately persuading President Mandela (1994-99) to adopt a series of structural adjustment and sectoral adjustment programs fully in line with the Washington consensus" (Bond 2011a, p. 355). Neo-liberalism, according to James Ferguson, deploys government structures to the benefit of the market, "so that even core functions of the state are either subcontracted out to private providers, or run (as the saying has it) 'like a business"' (Ferguson 2009, p. 172). Revealing evidence of the transition from apartheid capitalism to post-apartheid neo-liberal capitalism lies in the neo-liberal principles of the government's Growth, Employment and Redistribution (GEAR) strategy, which Marais describes as "deficit reduction, keeping inflation in the single digits, trade liberalization, privatization, tax cuts and holidays, phasing out of exchange controls etc." (Marais 1998, p. 171).

As expectation continued that post-apartheid economic changes would benefit the Black majority, several critiques of neo-liberalism have emerged over the years. Magubane laments, "There is no question that neo-liberalism has failed in terms of its announced goals, particularly in terms of bringing about rapid economic growth, reduced poverty, or economic stability" (Magubane 2004, p. 665). On the outcomes of the transition to neo-liberalism, Bond remarks that "the framework of neo-liberal, low-intensity democracy, the secretly negotiated terms of elite transition provided benefits for a few hundred at the top of the three divergent interest groups: White Afrikaners, White English-speaking business and the liberation movement" (Bond 2011b, p. 115).

According to these critiques, liberalism, neo-liberalism and liberal democracy have not created the conditions to redress apartheid structural racial inequalities in ways that could radically transform the lives of the historically-disadvantaged Black majority. As a consequence it could be argued that a transition to social democracy may create greater possibilities for redressing apartheid structural racial inequalities.

\section{Transition to post-apartheid social democratic capitalism}

Webster and Adler (1999), Marais (2001) and Terreblanche (2002) are among thinkers who promote social democracy as an alternative to neo-liberalism. In questioning whether the British-American version of democratic capitalism premised upon the ideology of liberal democracy suits the developmental needs of developing countries like South Africa, Terreblanche proposes "a social democratic version of democratic capitalism" (Terreblanche 2002, p. 477).

Webster and Adler (1999) used the conundrum "double transition" to describe the political and economic changes which occurred during the 1990 s and around the time of the 1994 elections in South Africa. They propose that class compromise is the antidote to counteract a conservative pact emanating from the double transition which is seen in "states that are simultaneously consolidating democracy and reconstructing their economies" (ibid., p. 348). Following Adam Przeworski et al. (1995) and the example of Kerala state (India), they promote "social democracy as an 
alternative to neo-liberalism" through which two compromises will be bargained, "a social wage to all citizens" and increased influence by workers over key economic decisions "to ensure that surpluses generated by growth benefit the population as a whole" (Webster and Adler 1999, p. 357). Well-known for his thinking about transitions to democracy, Przeworski contends that "The fundamental premise of social democracy is that nationalization of the means of production is not necessary to overcome the irrationality of capitalism, that is, to avoid the welfare losses caused by the rights inherent in private ownership of the means of production" (Przeworski 1991, p. 132).

Although there have been continuous prompts for social democracy in South Africa, it is critical to note that these are informed by different political and economic perspectives, both in terms of the rationale and the processes for achieving the alternative. Class compromise is the process which Webster and Adler (1999) envision for the attainment of a social democracy, while Terreblanche proposes that the governing elite orient themselves towards the "common good", which he considers a "basic precept of democracy" (Terreblanche 2002, p. 463). Terreblanche (2002) and Webster and Adler (1999) agree that social democracy has not been achieved. This is in contrast to others, notably Alan Hirsch (2005), who asserts that the South African government has shifted to social democracy. Although social democracy and a "social democratic vision" are represented in former President Mbeki's "two nations" thesis, 4 Stephen Gelb expresses little confidence that it would yield its proposed equality (Gelb 2003, pp. 54-56). The expression of the "two nations" perspective has manifested as a "two economies" concept, in the formulation and implementation of the Accelerated Shared Growth Initiative in South Africa (ASGI-SA) in 2006. However, binding constraints on shared growth limited the potential successes of the ASGI-SA (Dube et al. 2007). Haroon Bhorat et al. (2002) refer to South Africa as a "lean social democracy", but do not provide an elaborated conceptualisation of the latter. Likewise, Paul Benjamin (2006) makes bold reference to it, but also does not detail the notion of a "lean social democracy".

Taking into consideration these different theoretical perspectives, it becomes apparent that as the post-apartheid capitalist society has evolved, its political features have been characterised in multiple ways that include liberalism, neo- liberalism, liberal democracy and social democracy. The ways in which these different features coexist are explained well by Ferguson in his references to the Basic Income Grant (BIG) 5 that has been implemented in South Africa (Ferguson 2009, p. 176). He purports that an interwoven multiplicity of rationalities underpins the rationales for

\footnotetext{
${ }^{4}$ Thabo Mbeki declared his "two nations thesis" in his address to the National Council of Provinces on 11 November 2003, arguing that South Africa was characterised by two parallel economies, the First and the Second. He described these as follows, "The First Economy is modern, produces the bulk of our country's wealth, and is integrated within the global economy. The Second Economy (or the Marginalised Economy) is characterised by underdevelopment, contributes little to the GDP, contains a big percentage of our population [...] and is incapable of self-generated growth and development" (Mbeki 2003).

${ }^{5}$ The Basic Income Grant (BIG) is a form of social assistance paid by the government to all vulnerable South Africans. For further information, see DSD (2002).
} 
the BIG, such as "traditional welfare-state arguments", and "Keynesian arguments" that "lie side by side with others, which are markedly different from social democratic reasoning, and surprisingly similar to the neo- liberal rationality that we more usually associate with anti-welfare discourses" (ibid., p. 176). He expands this idea by stating his interest "in identifying some surprising ways in which certain discursive 'moves' that we can readily identify as neo-liberal are being put to work in the service of apparently pro-poor and pro- welfare political arguments" (ibid., p. 176).

Post-apartheid capitalism is complex and convergences and divergences are apparent among the different rationalities that operate simultaneously. This is the nature of the post-apartheid capitalism in which government and several institutions in South Africa are redressing apartheid inequalities in terms of skills development and unemployment. Notwithstanding the credibility and relevance of the arguments about the different rationalities, I wish to point out that above all, capitalism still prevails and remains an important dimension in my analyses of current and future transitions in this article.

The next question is "To what extent have the transitions from apartheid capitalism to post-apartheid capitalism provided the conditions to redress apartheid structural racial inequalities in terms of skills development and unemployment?" In addressing this question, it is useful to look at some socio-political and economic conditions in the apartheid capitalist society which marginalised Black people in terms of skills, employment and income, and prevailed around 1994.

\section{Skills levels, division of labour, employment/unemployment and income inequalities as of 1994}

Saul and Gelb's analysis of developments in the 1960s and 1970s, captured in the following statement, provides an historical backdrop for this section,

A permanently high rate of Black unemployment was, Legassick and Wolpe argue, an important condition of the postwar emergence of secondary industry. The large reserve army of unemployed was crucial in facilitating the reinforcement of the exploitation color bar, allowing the "living wage" for Blacks to be pegged at little more than the physical subsistence in the reserves, while compounding the difficulties of working-class organization (already restricted by harsh legislation). Yet, as even the very high growth rates of the 1960 os failed to create sufficient jobs to absorb the growing labor force (partly because of a bias toward capital-intensive investment), unemployment rose steeply, reaching over 12 percent in 1970 and defining a looming political threat. As then-Prime Minister John Vorster noted: "The biggest danger in South Africa today is not terrorism, but unemployment" (Saul and Gelb 1986, p. 71).

By 1994 there was convincing evidence that under apartheid, conditions created a significant majority of low-skilled Black people who occupied low-ranking jobs. Mark 
Orkin's statistical analysis of the occupations of people employed in the formal economy in 1996 shows that 50 per cent of African females were employed in low-ranking, menial jobs, in comparison with almost 50 per cent of White women who were in clerical work. Sixty-six per cent of White men were in management, blue-collar and semi-professional jobs. A further breakdown of Orkin's statistics shows that amongst employed Africans, 34\% of males and 50\% of females are working in elementary occupations such as cleaning, garbage collecting and agricultural labour. A further $20 \%$ of African males are in operator, assembler and related occupations, for example they are working as assembly-line operators. Approximately 20\% of African females are in semi-professional occupations, for example nursing assistants. Fewer than $4 \%$ of African males and $2 \%$ of African females are in managerial posts" (Orkin 1996, p. 18).

His analysis also shows that

Whites, on the other hand, particularly White males, tend to have access to occupations requiring higher levels of competencies. White males tend to be found in three main occupational categories, management (19\%), blue-collar jobs (29\%), semi-professional/technical category (17\%). White females, however, tend to be found largely in clerical occupations (47\%) (ibid., p. 18).

These structural class, race and gender inequalities in the distribution of occupations reflect the class, race and gender patterns which characterise income inequality. By 1994 synergies between colonialism, apartheid and racial capitalism had created a society in which political, economic and social conditions had relegated Black people to the lowest echelons of the labour force, who were occupying the most menial, and the lowest-paid jobs, and earning the lowest incomes. An analysis of structural income inequality in the early 1990s reveals race and gender inequalities in the composition of South Africa's poor population, high income inequalities between White and African people, and that African people were poorest. The average income of 68.6 per cent of African workers was less than R1, 600 a month, and the average income of 65 per cent of workers within the White population was between R3,201 and R25,600 (UNDP 2003, p. 148). Julian May, in a study on poverty and inequality, claims that in 1993, 50 per cent of the population could be considered poor (May 2000, p. xiii). This resonates with the United Nations Development Programme (UNDP), whose researchers for the purpose of their study used the South African government's Income and Expenditure Survey (IES) of 1995 to establish a national poverty line of R354 per month per adult for 1995 (Statistics South Africa 1995). Using this unit of analysis, the UNDP deduced that in 1995, 20.2 million people were living below the poverty line (UNDP 2003, p. 41).

Income inequality is determined, among other factors, by unemployment. Unsurprisingly, given South Africa's apartheid history, statistics reveal that access to employment continues to reflect race and gender inequalities. Given the low levels of 
skills among Black people occupying low-paid jobs, the projections for employment and unemployment are telling. Statistical analysis shows that of the 14.4 million who were economically active in 1995 (Orkin 1996, p. 13) "African economically active women are most likely to be unemployed (47\%), followed by African males (29\%), and then by coloured women (28\%). White females $(8 \%)$ and males (4\%) are least likely to be unemployed" (Orkin 1996, p. 15).

As illustrated earlier, low-skilled Black people access low-income jobs and have limited opportunities for any employment. Premised on the argument that higher skills levels can increase employability, access to employment and access to higherwaged jobs, the post-1994 government set up a non-racial, non-sexist system that expands access to skills development opportunities for Black people.

\section{Skills development and structural changes: promises, targets and outcomes}

Wolpe's poignant description of the racial features of apartheid capitalism reads as follows:

It is clear that race is inscribed in the institutional and organisational structures at every level of the political and economic system. Race is, thus, a critical ingredient of the political and economic structure but, as has been argued throughout, it by no means exhausts the account of what is significant to the functioning of those structures (Wolpe 1988, p. 63).

This serves as a point of reference in considering the kinds of changes that the post1994 government instituted to redress structural racial inequalities. Some literature (Groener 1997, 2000; Badroodien 2004; Kraak 2004b; McGrath 2004) sketches the history of apartheid, training and skills development. The skills crisis itself is discussed by Andre Kraak (2004b, 2005) and Simon McGrath (2004), work which is pertinent to understanding post-1994 changes of the apartheid forms of training. Under apartheid, the Department of Manpower (DOM) ${ }^{6}$ coordinated a raciallydefined system of training governed by the Manpower Training Act (DOL 1981). Institutional arrangements under the apartheid government reflect the raciallydefined systems of delivery, comprising the DOM, which delivered training for White people, and, to some extent, for Indian and Coloured people. The homeland governments provided vocational training for African people. These apartheid institutional structures created structural racial inequalities between the provision of higher-standard and well-resourced training for White people, and low-standard, under-resourced training for Black people.

\footnotetext{
6 "The Department of Manpower (DoM) was supposedly in charge of co-ordinating all matters relating to the training of workers in the private sector. However, there were separate manpower departments in each of the nominally independent homelands. In addition, the administration of training for local authorities, the public sector and some parastatals were handled by these structures independently of the DoM" (Kraak 2004a, p. 51).
} 


\section{Post-1994 changes in skills development}

Several authors have researched post-1994 changes in skills development. Among others, Azeem Badroodien (2004) assessed the size of the problem; Marina Mayer and Miriam Altman (2005) outlined the implications for skills development and South Africa's economic development trajectory; and Andre Kraak (2004a) described the National Skills Development Strategy (NSDS) in post-apartheid South Africa. As the literature attests, the post-1994 government aimed to redress the structural racial inequalities by expanding the hitherto limited and under- resourced provision of training through expanding provision for Black, low-skilled and unemployed adults and youth.

Several new policies were introduced by the post-1994 government, which include the Green Paper Skills Development Strategy for Economic and Employment Growth in South Africa (Office of the President 1997); the Skills Development Act (Office of the President 1998a); the Skills Levies Act (Office of the President 1998b); and the NSDS 2001-2010 launched in 2001.7 Also of importance are the government's White Paper on Reconstruction and Development (Office of the President 1994); and the Growth, Employment and Redistribution document (Office of the President 1996), since these have presented the broad political and economic frameworks within which the government has formulated its skills development policies. The government created new sources of funding by instituting an imposed skills levy on particular kinds of organisations. These levies are channelled into the National Skills Fund (NSF), and the Sector Education and Training Authorities (SETAs) are among those who distribute these funds for skills development programmes. ${ }^{8}$ Through the SETAs the government has established a system of providing skills development programmes, such as learnerships, ${ }^{9}$ learning programmes and skills programmes.

\section{Promises and equity targets}

As the government instituted changes, they made promises and set targets to achieve equity. A promise "to redress those disadvantages through training and education" is explicit in one of the purposes of the Skills Development Act (DOL 1998, pp. 4-5). Further promises to redress inequalities through skills development are expressed in the equity targets which are captured in the NSDS (DOL 2006a). The promises of equity through skills development for designated groups, defined as Black people, women, and people with disabilities, are stated clearly in the NSDS Implementation Reports. The South African Department of Labour (DOL) declares that "equity targets underpin every objective of the NSDS. These targets state that the

\footnotetext{
7 The National Skills Development Strategy (NSDS) was divided into two phases: NSDS I (2001-2005); NSDS II (2005-2010). In the meantime, NSDS III (2011-2016) has been implemented.

${ }^{8}$ Established in the Skills Development Act in 1998, the National Skills Fund (NSF) is is a fund located within the Department of Labour. The Sector Education and Training Authorities (SETAs) are regional branches of a vocational skills training organisation in South Africa, responsible for managing and creating learnerships, internships, unit-based skills programmes, and apprenticeships within their jurisdiction.

Learnerships, discussed in more detail later on in this paper, are fixed-term legal contracts between a learner, an employer and a training provider. The scheme of learnerships (2001-2005) was followed by the scheme of learning programmes (2005-2007) which include structured learning programmes, learnerships, apprenticeships and skills programmes.
} 
beneficiaries of the strategy should be $85 \%$ Black, $54 \%$ female and $4 \%$ people with disabilities" (DOL 2003, p. 48). This commitment was re-stated in 2006 in the following way: "The achievement of equity targets in the NSDS 2005-2010 is therefore critical to the previously-disadvantaged" (DOL 2006b, p. 32). "Unemployed youth" was added as a designated group in the NSDS 2005-2010 (ibid., p. 32). The identification of these designated groups and equity targets implies that the NSDS aims to redress social inequalities which arise from class, race, gender, disability, and employment status - between ruling class, middle class, working class; African, coloured, Indian and White; men and women; able-bodied and disabled; and employed adults and unemployed youth.

Despite this explicit political and moral commitment to address inequalities, skills development outcomes in South Africa are not encouraging 20 years after the democratic elections. Several years have passed since the promulgation and implementation of the post-1994 skills development policies. There has been some progress. Reports on post-1994 delivery indicate that skills development has succeeded in redressing inequalities related to opportunities for skills development to a limited extent. Dismantling the racially-defined system of vocational education and training has eliminated some of the structural racial inequalities which created, for Black people, structural barriers to access skills development opportunities. The DOL's own assessment of its successes and failures in terms of selected objectives and principles in instructive. In its NSDS, the DOL identified objectives against which it has monitored and evaluated its performance. These were modified in 2005 to incorporate "designated groups" more consciously in terms of learning programmes and employment, evident in Objective 4, "Assisting designated groups, including new entrants, to participate in accredited work, integrated learning and work-based programmes to acquire critical skills to enter the labour market and self-employment" (DOL 2006b, p. iii). The relationship between the equity targets in relation to broader political and economic goals is conveyed in the following statement: "These five objectives ${ }^{10}$ are central to the achievement of the overall objective of the strategy, which is to contribute towards halving unemployment and poverty, and reducing inequality by 2014" (ibid., p. viii).

\section{Equity targets for designated groups: impact}

Are equity targets for access by designated groups being met? For NSDS II the DOL identified guiding principles, among others, Principle No. 3, the "Achievement of Equity Targets", as criteria against which to monitor and evaluate its progress towards redressing inequalities (DOL 2007a, p. 41). Their assessment of progress has

\footnotetext{
${ }^{10}$ The five objectives of the National Skills Development Strategy II (2005-2010) referred to here are (1) Prioritising and communicating critical skills for sustainable growth, development and equity; (2) Promoting and accelerating quality training for all in the workplace; (3) Promoting employability and sustainable livelihoods through skills development; (4) Assisting designated groups, including new entrants to participate in accredited work, integrated learning and work-based programmes to acquire critical skills to enter the labour market and self-employment; and (5) Improving the quality and Footnote 10 continued

relevance of provision. These have been modified and changed from the objectives of the National Skills Development Strategy I (2001-2005).
} 
presented evidence that during the period 2001-2008 very few promised equity targets were met. While there has been some advancement during this period, a grim picture has emerged from the DOL's revealing statements. In 2004 some changes were reported by the DOL, claiming "slow progress towards meeting the equity targets" (DOL 2004, p. 62). Some successes were acknowledged: "There has [sic] been some clear improvements in this regard during 2003/o4" (ibid., p. 62), but the following year the DOL declared a "general dissatisfaction with regard to the achievement of equity targets" (DOL 2005, p. 60). 2007 reports conveyed shocking messages that "no equity targets were met" (DOL 2007a, p. 41); "equity targets in all categories could not be met in the 2006/o7 financial year" (ibid., p. 44); and none of the targets were realised (DOL 2008, p. 59). In terms of equity targets, "SETAs are still trailing behind. There is however an improvement in the percentage of people with disabilities entering and completing learning programmes" (DOL 2007a, p. 30). This is disconcerting as the government has placed SETAs at the helm of redressing inequalities in terms of skills development.

Evidence over the years 2002-07 arising from their evaluation of equity targets in terms of race, gender and disability gives further insights. Women remain at the margins, according to the DOL's statement that, "similarly women are also still excluded from apprenticeship and, to some extent, other learning opportunities" (DOL 2003, p. 52). Limited achievement of race and gender targets was reported in 2004 and 2005 (DOL 2004, p. 62; DOL 2005, p. 60). Black disabled people remained at the margins of the government's equity achievements. This is revealed in the admission, "In particular none of the disability targets are currently being met in areas where Black people have historically been disadvantaged (e.g. in structured learning opportunities and completion of apprenticeships)" (DOL 2003, p. 52). Given the high rate of low literacy among Black adults, failure to achieve equity targets led to the Director-General of Labour's statement,

I believe that we have absolutely no excuse with regard to adult basic education and training (ABET) and the agreed equity targets especially if we are to address the inequalities created by the past apartheid system (DOL 2007a: foreword).

Projecting ahead, and pointing to the relationship between skills development and structural features of the economy such as work, the DOL declared that "It is imperative that more Blacks, women and people with disabilities need to be taken into learning programmes to ensure that the strategy addresses inequalities in the workplaces and economic activities" (ibid., p. 41). To illustrate further successes and failures of the NSDS, some statistics about Black low-skilled, unemployed adults and youth in (1) learnerships (2001-2005) and (2) learning programmes (2005-2007) and their access to the labour market and employment are given below.

Learnerships 2001-2005: access and success, impact 
A system of skills development, including learnerships, learning programmes and skills programmes was created by the government in 2001. The enrolment target 2001-2010 was set at 125,000 unemployed learners in learning programmes. Learnerships targeted both employed and unemployed learners.

By March 2005, 134,223 learnership agreements were registered, of which 45,813 concerned employed workers (DOL 2005, p. 49) and almost twice as many, 88,410, concerned unemployed learners (ibid., p. 48). Given these enrolment figures, it is clear that access to skills development programmes has created new opportunities among employed and unemployed people. Learnerships have contributed to reducing inequalities in access to skills development opportunities for the unemployed. Nevertheless, given the extensive needs, and the limited scale of such access, it is clear that inequalities among designated groups persist and that the original target was conservative. In this regard, the DOL admitted that

Achieving equity targets continues to be a challenge for the implementation of the NSDS. In particular none of the disability targets are currently being met in areas where Black people have historically been disadvantaged (e.g. in structured learning opportunities and completion of apprenticeships) and similarly women are also still excluded from apprenticeship and, to some extent, other learning opportunities (DOL 2003, p. 52).

Completion rates are a matter of concern. By March 2002, 315,836 workers were registered in structured learning programmes, which include learnerships and apprenticeships. Of these, only 50,683 (16\%) had completed their training by 2003 (ibid., p. 17), and by March 2003, 4,008 learners, comprising 1,470 unemployed and 2,538 employed learners out of the 25,341 registered learnership agreements completed their learnerships. A discussion of completion rates during the years 2005-2007 in the next section provides further insights.

Learning programmes 2005-2007: access and success, impact

Statistics for enrolments and completions in learning programmes in the years 2005-2007 are instructive in understanding access and success. It is important to note that during the implementation of NSDS II (2005-2010), the DOL expanded the category "structured learning programmes" to include skills programmes as well (DOL 2006b, p. 23). This category does not enable us to assess the impact of the differentiated learning opportunities provided for Black, low-skilled and unemployed adults and youth. It should however be noted that some statistics do also distinguish between these categories.

To illustrate the above, taking for example the years 2005-2007, the evidence about the low completion rates among unemployed people is revealing and alarming. According to the DOL, only 16,507 out of 87,687 of the registered unemployed 
learners in learning programmes, mostly unemployed youth, completed their training from April 2005 to March 2007. In response, the DOL remarked that, "The challenge is that the completion rate is still low at 19\%" (DOL 2007a, p. 30). Further statistics show that of the total number of unemployed in learning programmes over the period 2005 to 2007 ,

$79 \%$ were Blacks, $46 \%$ women, $3 \%$ people with disabilities and $69 \%$ youth. Of those completing learning programmes, $72 \%$ were Blacks, $32 \%$ women, $2 \%$ people with disabilities and $59 \%$ youth (ibid., p. 30 ).

Despite the low completion rates, as stated earlier, it is important to recognise that the transition from the apartheid political economy, the development of non-racial policies and systems, and the creation of new resources have enabled Black, lowskilled and unemployed adults and youth to access skills development programmes. In my view, low completion rates may be attributed to several structural and pedagogical barriers. (1) Learners may enter these skills development programmes with lower levels of academic skills, literacy and numeracy than those assumed for success; (2) the skills development programmes may not match their prior learning experiences; (3) academic support for learners may not be available; (4) stipends may not be sufficient to cover all costs that can enable Black, low-skilled and unemployed adults and youth to access skills development opportunities; and (5) low numbers are targeted for skills development programmes.

My identification of these barriers is substantiated by research findings. Funding and finances feature prominently as an institutional barrier: lack of government financial support (HRSDC/CMEC 1997); lack of transportation support services (e.g. reduced-cost bus pass, and the resulting lower cost of getting to and from educational activities) (Millar and Falk 2000; OECD 2002; U.S. Department of Education 1998); lack of adequate childcare services and financial support to pay for such services (McGivney 1999; OECD 2002; Myers and De Broucker 2006, p. 30, pp. 41-44); lack of public funding to support the learning activities of learners with low and middle incomes (Lowe 2001); declining overall social support spending resulting in government training funds being focused on the unemployed (HRDC/ CMEC 1997); and costs of registering and purchasing learning materials (Potter and Ferguson 2003). Moreover, a lack of "external support (i.e. from employers or government), especially for disadvantaged groups, is a significant barrier to participation in AET" (Desjardins et al. 2006, p. 105).11

Given these barriers, the following changes could be made by the government to improve the completion rates:

\footnotetext{
${ }^{11}$ AET stands for Adult Education and Training.
} 
(1) provide school-leaving qualifications tailored to the needs of Black, low- skilled and unemployed adults and youth;

(2) provide a "living wage"; and a "tuition fee waiver" for Black, low-skilled and unemployed adults and youth to complete or improve their school-leaving qualifications so that they are academically more prepared to study in skills development programmes;

(3) integrate skills development programmes into a qualifications/career pathway so that these are not regarded as "training skilled cheap labour".

Structural changes are also imperative. Socio-economic and political structures should be transformed more radically in order to address, more fundamentally, the structural barriers to skills development, such as policy, funding and systems of delivery. The DOL and the Department of Higher Education and Training (DHET) should change policies in ways to prioritise the skills development needs of Black, low-skilled and unemployed adults and youth. The DOL, the DHET, the SETAs and various other institutions should make more funding available to cover learners' costs such as transport, childcare, and supplementary income grants. These institutions should also change systems of delivery in order to provide skills development programmes during the day and in the evenings in schools and in other vacant public and private community buildings.

In summary, promises about addressing structural racial inequalities were made, a new system of skills development was implemented, yet the evidence shows that structural racial inequalities persist. Evidence in the data from the DOL reports illustrates that for designated groups and the unemployed access to skills development has been created, participation has increased, but success has been limited. So far, this analysis of the relationship between skills development and inequality reveals that skills development in South Africa under post-apartheid capitalism is redressing some inequalities, albeit to an extremely limited extent, while still reproducing apartheid inequalities, and creating new inequalities.

\section{Skills development and access to the labour market for designated groups}

\section{Promises and equity targets}

Promises were made to employed workers "to improve the quality of life of workers, their prospects of work and labour mobility"; and to the unemployed, "to encourage employers to provide opportunities for new entrants to the labour market to gain work experience"; "to promote self-employment"; "to employ persons who find it difficult to be employed"; "to assist work-seekers to find work"; "'to assist retrenched workers to re-enter the labour market" and "to improve the employment prospects of persons previously disadvantaged by unfair discrimination" (DOL 1998, pp. 4-5). The most critical issue is that promises of equity are based on the assumption that "the market" is an active player in providing or redistributing employment opportunities for people "skilled" under the new regime of skills development. 
The promise of employability is explicit in the relationship between skills development, the labour market and work. This is conveyed in the DOL's statements, "The NSDS is aimed at addressing the structural problems of the labour market inherited from the past, and aimed at transforming the South African labour market from one with a low skills base to one characterised by rising skills and a commitment to lifelong learning" (DOL 2004, p. 1); and "Transformation remains at the forefront of all skills development activities so as to create employment opportunities for previously disadvantaged communities of our country" (DOL 2006b, p. 32). The DOL emphasises the promise of equity as an economic gain in the following statements: "Ensuring equity in skills development is also critical to addressing the skills constraints that are faced by the South African economy" (DOL 2003, p. 48); and "Equity is an essential principle for the transformation of economic relations broadly, education and training more specifically, and for ensuring that the legacy of apartheid is addressed" (ibid., p. 48).

\section{Access to employment: impact}

According to the Skills Development Act (DOL 1998), skills development is intended to redress the inequalities in skills development for adults in order for them to access employment and income opportunities. These (promises expressed in) intentions of the Act are given in Objective 4 of the NSDS, "Assisting designated groups, including new entrants to participate in accredited work, integrated learning and work-based programmes to acquire critical skills to enter the labour market and self-employment" (DOL 2006b, p. iii). In this way the policy has projected skills development as a vehicle to address "the structural problems of the labour market inherited from the past" (DOL 2003, p. 1).

\section{Entry level skills}

The litmus test for assessing the success of learnerships is to establish whether people find employment. According to the DOL, statistics provided by the SETAs in this regard are biased as they tend to report on best practice only. These statistics show that among the SETAs, there is an overall average of 79 per cent for successful placement into employment, while the Financial and Accounting Services Sector Education and Training (FASSET) SETA has recorded 100 per cent (Butcher 2007) and the Wholesale and Retail Learnership with Shoprite and Checkers ${ }^{12}$ indicates a placement rate of 100 per cent (DOL $2007 \mathrm{~b}, \mathrm{p}$. 31). These figures seem to point to a high degree of success.

Evidence does indicate that some learnerships have served as a vehicle for access to employment, provided that employment is available to absorb new entrants. Furthermore, if employment opportunities are available, and they match the skills development in the respective learnership, then it is possible that learnerships can

\footnotetext{
${ }^{12}$ Shoprite and Checkers are South Africa's two biggest food retailers.
} 
provide access to employment for Black, low-skilled and unemployed adults and youth, and those in designated groups, thus redressing inequalities.

If people succeed in equipping themselves with skills for employment through learnerships, but are then unable to access employment, success of/in skills development would be evident in the increase of a larger pool of higher-skilled people who have qualifications. According to the most recent Labour Force Survey there were 4,336 million unemployed people in March 2007 (Statistics South Africa 2007, p. iii). As stated earlier, only 16,507 , mostly unemployed youth (i.e. $18.8 \%$ ), of the 87,687 registered learners completed learning programmes between 2005 and 2007. Although a high rate of placement in employment was reported as best practice, the low completion rates with regard to learnerships do not hold promise for a significant contribution on the scale which is required to address the need for employment among 4,336 million unemployed people. These statistics reveal that while learnerships for Black, low-skilled and unemployed adults and youth do present opportunities for access to low-skilled employment, the potential for impacting national unemployment is in fact limited.

\section{Higher skills}

Renee Grawitzky's investigation into the implementation of learnerships, commissioned by the Development Policy Research Unit (DPRU) located at the University of Cape Town, provides the following explanations,

A large number of the learnerships have been initiated at the lower (NQF level 1) rather than intermediary skills levels. This might partly be a result of a drive by government to meet specific targets to employ unemployed youth. (It could also be a way of employing cheap labour, which has occurred and had led to the displacement of permanently employed workers). If that is the case, then the system has not had the desired effect of increasing the level of skills at the intermediary to higher levels of the skills spectrum (Grawitzky 2007, p. 34).

Since the majority of learnerships are concentrated at the low skills end of the labour market, successful completion of learnerships and placement in employment implies access to low-skilled, low-paid work. It is unlikely that learnerships located at low skills levels can provide access to higher-skilled employment. Given the historical legacy of apartheid inequalities in the labour market, in which most high- skilled jobs were occupied by White people and almost all low-skilled jobs by Black people, and the low success rate in learnerships, there seems a slim chance that learnerships could enable upward mobility for Black people into higher-skilled jobs and higher income levels and reach the target of "halving unemployment and poverty, and reducing inequality by 2014" (DOL 2006b, p. viii). 
Despite the changes discussed above, it is evident that skills development is addressing employment and income inequalities in a limited way. There are no available comprehensive statistics to show the relationship between skills development and structural racial inequalities related to employment/unemployment and income in relation to class, race and gender. However, for extrapolation and inference, it is possible to discern broad trends in emerging statistics which indicate the persistence of apartheid structural class, race and gender inequalities in the distribution of employment, division of labour and income. They mirror the trends and patterns identifiable in the evidence on the limited impact of learnerships and learning programmes on national unemployment among Black, low-skilled and unemployed adults and youth.

\section{Unemployment}

Mayer and Altman argue that the unemployment rate which has risen from 20 per cent in 1994 to 30.5 per cent in 2002, especially among unskilled African workers, has contributed to an increase in poverty and inequality during the democratic era (Mayer and Altman 2005, p. 42). Government statistics show that in March 2007, the unemployment rate among Black Africans was 30.2 per cent, as against 19.8 per cent among coloured people, 13.8 per cent among Indians/Asians, and 4.3 per cent among White people (Statistics South Africa 2007, p. xv). Orkin concludes that these racial inequalities reflected in statistics on unemployment in 2007 do not reflect major changes according to the trends evident in 1994-1995 (Orkin 1996, p. 15).

Gender inequalities are also discernible in the unemployment figures for 20062007 , which indicate that Black African women continue to be most disadvantaged with respect to employment: Black African (36.4\%); Coloured (22.7\%); Indian/ Asian (17.9\%); White (4.6\%). Similar trends are evident among men: Black African (25.0\%); Coloured (16.9\%); Indian/Asian (11.3\%); White (4.1\%) (Statistics South Africa 2007, p. xvi).

Oeindrila Dube et al., quoting Abhijit Banerjee, reveal that "South Africa's unemployment rate [...] stands today at 26 percent [...] which excludes discouraged workers [...]. The unemployment rate including discouraged workers is 40 percent, which is one of the highest in the world" (Dube et al. 2007, p. 8). According to Dube et al., "[...] the rate has risen from 12 to 23 percent for men and from 21 to 32 percent for women, over 1995 to 2005 " (ibid., p. 8). ${ }^{13}$

If learnerships and learning programmes are directed at redressing structural racial inequalities related to unemployment, and their successes at arresting increasing unemployment are limited, then the DOL, DHET and other institutions must improve these initiatives, reduce the expectations of these initiatives in terms of

\footnotetext{
${ }^{13}$ In the third quarter of 2013 Statistics South Africa established the unemployment rate at 24.7 per cent of a total population of 51.8 million according to the Population Census 2011. See http://beta2.statssa. gov.za/, accessed 15 January 2014.
} 
unemployment, and find other ways of addressing unemployment in more fundamental ways.

\section{Post-apartheid capitalism and its limitations for redressing apartheid structural racial inequality in terms of skills development and employment}

Despite limited successes, the DOL continues to assert that "Transformation remains at the forefront of all skills development activities so as to create employment opportunities for previously disadvantaged communities of our country" (DOL 2006b). As critics highlighted the limitations of liberal democratic capitalism for redressing apartheid structural racial inequalities, social democracy was proposed, and found expression in the government's Accelerated Shared Growth Initiative for South Africa (ASGI-SA) established in 2006. ${ }^{14}$ Through the ASGI-SA the government prioritised skills development as follows, "Finally, the sixth objective is to raise the coordination between skills needs and skills supply, through immigration reform, and improvements in training programs and in the quality of [the] educational system" (Dube et al. 2007, p. 2).

Dube et al. argue that "Skills act as a binding constraint to economic growth" (ibid., p. 27). The relationship between skills demand, shrinking sectors in the economy and structural unemployment is illuminated by their analysis of structural changes in the "non-mineral tradables (including manufacturing) sector" (ibid., p. 11). Stating as a starting-point that "most of the unemployment is in fact structural" (ibid., p. 39), they claim that the non-mineral tradables sectors (including manufacturing) "are relatively intensive in the use of unskilled labor in comparison to other sectors of the economy" (ibid., p. 12), but point out that "changes in the sectoral composition of the South African economy have lowered the relative demand for unskilled labour" [...] "resulting in high unemployment rates for these workers. and favored skilled workers" (ibid., p. 33).

If skills act as a binding constraint to economic growth, then unskilled labour will undermine economic growth, and have limited opportunities to employment, while skilled labour will be privileged. Given that Black and White people constitute most of the unskilled and skilled labour respectively, a reproduction of structural racial inequalities could be implied.

If there is less demand for unskilled labour, why should the unskilled be afforded skills development opportunities? Is skills development, in this instance, a mere political appeasement, or is it an authentic attempt to re-skill unskilled labour? The width, depth and pace of change in terms of skills development and its contribution to addressing unemployment will be determined by the developments in the broader socio-economic and political context. Be that as it may, the limited successes in ${ }^{14}$ The Accelerated Shared Growth Initiative for South Africa (ASGI-SA) was implemented by the South African government
in 2006 to address the second economy as identified by then-President Mbeki in 2003. See footnote 4 for further explanation. 
redressing inequalities in skills development opportunities as such, and as a strategy to redress unemployment and various other inequalities, prompt further thinking.

The logic underpinning the government's initiatives in terms of skills development is that the latter would provide opportunities for employment and in this way redress income inequality. If employment however is not available, then skills development will fail to redress racial income inequality and unemployment will remain a driver of this inequality. Several studies, including those by Bhorat et al. (2002), DPRU (2010), Leite et al. (2006), Leibrandt et al. (2005), Seekings et al. (2004), Seekings and Nattrass (2005) and Seekings (2007), have investigated changes in income during the post-1994 period and provide evidence that racial inequalities endure in the changes in income inequality. Analysing various datasets over the years 1995 to 2005, the Development Policy Research Unit (DPRU) found that "Generally the inequality measures show that income inequality has increased considerably across race groups over the period under discussion" (DPRU 2010, p. 4). Philippe Leite et al. concur, arguing that earnings inequality during the period 1995 to 2004 "rose sharply initially and then fell marginally" (Leite et al. 2006, p. 25). Reporting on post-1994 research, Gelb declared that,

Not surprisingly, race is a significant determinant of both poverty and inequality. Based on a household poverty line of US $\$ 220$ per month in $1999,54 \%$ of the African population was poor while $95 \%$ of poor people were African, though Africans were only $79 \%$ of the population as a whole (Gelb 2003, p. 4).

Contrary to promise and expectation, the DPRU reported that "An unexpected result was that income inequality between race groups, rather than income inequality within race groups, was the leading cause of the increasing levels of income inequality" (DPRU 2010, p. 12).

Given the rise in unemployment, the increase in income inequalities, the limited access to and low participation and completion rates in skills development programmes, the evidence suggests that skills development has made a limited contribution to transforming skills development as such and redressing structural racial inequalities related to employment and income for Black, low-skilled and unemployed adults and youth. The logic of the promise that skills development will enable Black, low-skilled and unemployed adults and youth to develop skills, become employed and secure income is thus in question. In fact, the harsh reality is that while the government's initiatives to redress inequalities have unfolded, South Africa has become the most unequal society in the world.

Despite those structural changes which have already taken place, it is clear that the structural racial inequality which was created by apartheid persists. The scale of structural racial inequalities in South African society is wide and deep. So what does the persistence of these inequalities reveal about redressing inequalities in a post- 
apartheid context? Saul Gelb (2003) and Jeremy Seekings and Nicoli Nattrass (2005) provide insights into some complexities which should be taken into account. In his research, Gelb (2003, p. 7) discerns relationships among inequalities; among adult basic education, income inequality, poverty, class, race and gender. His notion of "multiple interlocking inequalities" is a useful construct for further analysing the relationship between skills development and multiple inequalities. Seekings and Nattrass, focusing specifically on income inequality, comment on the complexity of studying inequality, stating that, "The South African case illustrates how labour market, welfare, education, and economic policies combined to structure the pattern of income in society, sometimes exacerbating inequality, at other times reducing it" (Seekings and Nattrass 2005, p. 4). Quite clearly, further studies on inequality in the direction of a more comprehensive political and economic analysis of inequality are required for an understanding of inequalities related to skills development and employment, and the relationship between skills development, employment and inequalities.

Reflecting on the arguments presented thus far, there seems to be a paradox - that post-apartheid capitalism has enabled de-racialisation which created some possibilities for skills development to redress some inequalities related to the access of historically-disadvantaged Black people to learning opportunities, yet at the same time preserved historical racially-determined structural unemployment, which limits the possibilities for skills development to redress inequalities related to the access of many historically-disadvantaged Black people into employment. Two questions come to mind: (1) Can post-apartheid capitalism, in all its manifestations, redress the structural racial inequalities created by the apartheid capitalist political economy as described by Wolpe, Saul and Gelb in the 1980s? and (2) Can post-apartheid capitalism transform the lives of Black, low-skilled and unemployed adults and youth in radical ways?

Reflecting on transitions to post-apartheid capitalism, it becomes clear that the South African government has implemented various changes to de-racialise post- apartheid capitalism. Nevertheless, and given the current conditions, further questions arise: (3) Is it possible that the changes are not far-reaching enough to de-racialise post-apartheid capitalism in order to redress the structural racial inequalities created by apartheid which limit the possibilities of transforming the lives of Black, low-skilled and unemployed adults and youth? Is there any hope in Wolpe's thesis that capitalism and racism are contingent upon one another, and that capitalism can be de-racialised (Wolpe 1988)? (4) Or does the persistence of structural racial inequalities indicate a contradictory relationship between capitalism and racial domination, and that post-apartheid capitalism in South Africa should be dismantled in order to de-racialise it, as Saul and Gelb (1986) argued in the 1980s? In his current thinking about structural reform Saul (2011) may be suggesting this. 


\section{Structural reform}

Debates about structural reform started in the early 1990s and are gaining momentum. Focusing specifically on central issues of this article, I pose yet another question, "What are the possibilities that structural reform can transform postapartheid capitalism in ways that provide opportunities of skills development and employment which radically transform the lives of Black, low-skilled and unemployed adults and youth?" The following statement by Saul and Gelb provides a theoretical point of departure: "As Gelb and I argued, such problematic features link up, in turn, with constraints upon growth specific to South Africa's own racially structured brand of capitalism: the very pattern of racial stratification that has, historically, made cheap labour so readily available" (Saul and Gelb 1986, p. 217).

Of pertinence is Jacob Dlamini's reference to Saul's expression of the aim of structural reform "to deal with the structure of the South African economy" (Dlamini 2011, p. 39). In the early 1990 saul anticipated the limitations of the social transition and social transformation that would emerge from negotiations and urged a "focus, instead, on the attempts by many militants to think about structural reform" or a "future beyond the interregnum that begins to redress South Africa's severe socio-economic inequalities" (Saul 1992, p. 3). At present, there is much debate about

the meaning of reform. Saul draws on the work of Andre Gorz (1973) and points out that

Gorz makes a key distinction between a "genuinely socialist policy of reforms on the one hand [and] reformism of a neo-capitalist or 'social democratic' type" on the other. He writes that "If [most often] immediate socialism is not possible, neither is the achievement of reforms directly destructive of capitalism. [Yet] those who reject all lesser reforms on the grounds that they are merely reformist are in fact rejecting the whole possibility of a transitional strategy and of a process of transition to socialism (Saul 2010, p. 181).

The radical and organic nature of structural reform is revealed in Saul's articulations of the distinctions between "structural reform" and "mere reformism". As a way forward, Saul describes the key attributes of "structural reform" as follows:

any reform, to be structural [. ] must instead be allowed self-consciously to implicate other "necessary" reforms that flow from it as part of an emerging and on-going project of structural transformation in a left-ward direction. Secondly, a structural reform must root itself in popular initiatives in such a way as to leave a residue of further empowerment (ibid., p. 181).

\section{Conclusions}

Let me return to the question posed in the introduction, "What possibilities and limitations have the transitions from apartheid capitalism to post-apartheid 
capitalism created for redressing structural racial inequalities in terms of skills development and unemployment?"

After due consideration, we may conclude that some political and economic changes during the course of the transitions have created some possibilities to redress some structural racial inequalities in terms of skills development and unemployment. Limitations however are evident as well, which suggests that further de-racialisation and structural reform of post-apartheid capitalism are imperative to create greater possibilities for redressing structural inequalities in terms of skills development and unemployment on a larger scale.

At this particular historical juncture we are confronted with the following conundrum: Can further structural changes de-racialise capitalism and enable the government to redress structural racial inequalities created by apartheid? Or should capitalism be dismantled in order to de-racialise it and enable the government to redress structural racial inequalities created by apartheid? Only the future can tell! As the debates about structural reform ensue and the political and economic conditions become favourable for structural reform, possibilities may emerge for redressing structural racial inequalities in radical ways.

As the future unfolds, let us bear in mind the late Nelson Mandela's statement in the preface to the White Paper on Reconstruction and Development, My government's commitment to create a people-centred society of liberty binds us to the pursuit of the goals of freedom from want, freedom from hunger, freedom from deprivation, freedom from ignorance, freedom from suppression, and freedom from fear. These freedoms are fundamental to the guarantee of human dignity (Office of the President 1994, p. 6). 


\section{References}

Adler, G., \& Webster, E. (2001). Unions, democracy, and economic liberalization. In J. K. Coetzee, et al.

(Eds.), Development: Theory, policy, and practice. New York: Oxford University Press.

Alexander, N. (2003). An ordinary country; issues in transition from apartheid to democracy in South Africa. New York: Berghahn Books.

Badroodien, A. (2004). Technical and vocational education provision in South Africa from 1920 to 1970. In S. McGrath, A. Badroodien, A. Kraak and L. Unwin (eds), Shifting understandings of skills in South Africa: Overcoming the historical imprint of a low skills regime. Cape Town: Human Sciences Research Council Press.

Benjamin, P. (2006) Beyond "lean" social democracy: Labour law and the challenge of social protection. Transformation 6o. Accessed 22 November 2013 from http://www.transformation.ukzn.ac.za/index. $\mathrm{php} /$ transformation/article/view/964/779.

Bhorat, H., Lundall, P., \& Rospabe, S. (2002). The South African labour market in economic and legislative considerations. Employment Paper 2002/32. Geneva: International Labour Organisation (ILO).

Bhorat, H., \& Cassim, R. (2004). The challenge of growth, employment and poverty in the South African economy since democracy: An exploratory review of selected issues. Development Southern Africa, 21(1), 7-31.

Bond, P. (2000). Elite transition: From apartheid to neo-liberalism in South Africa. Pietermaritzburg, South Africa: Pluto Press; University of Natal Press.

Bond, P. (2011a). What is radical in neo-liberal-Nationalist South Africa? Review of Radical Political Economics, 43(3), 354-360.

Bond, P. (2011b). South African splinters: From "elite transition" to "small-a alliances". Review of African Political Economy, 38(127), 113-121.

Butcher, C. (2007). Making a difference. Mail \& Guardian 31 October. Accessed 31 December 2013 from http://mg.co.za/article/2007-10-31-making-a-difference.

Desjardins, R., Rubenson, K., \& Milana, M. (2006). Unequal chances to participate in adult learning: International perspectives. Paris: UNESCO.

Dlamini, J. (2011). We now know: Reform, revolution and race in post-apartheid South Africa.

Transformation: Critical Perspectives on Southern Africa, 75, 36-43.

DOL (Department of Labour). (1981). Manpower Training Act. Pretoria:

Department of Labour.

DOL (Department of Labour). (1998). Skills Development Act 1998. Pretoria: Department of Labour.

DOL (Department of Labour). (2001). National skills development strategy (NSDS) 2001-2005. Pretoria: Department of Labour.

DOL (Department of Labour). (2003). National skills development strategy: Implementation report. Pretoria: Department of Labour.

DOL (Department of Labour). (2004). National skills development strategy: Implementation report. Pretoria: Department of Labour. 
DOL (Department of Labour). (2005). National skills development strategy: Implementation report. Pretoria: Department of Labour.

DOL (Department of Labour). (2006a). National skills development strategy (NSDS) 2005-2010. Pretoria: Department of Labour.

DOL (Department of Labour). (2006b). National skills development strategy: Implementation report. Pretoria: Department of Labour.

DOL (Department of Labour). (2007a). National skills development strategy: Implementation report. Pretoria: Department of Labour.

DOL (Department of Labour). (2007b). State of skills in South Africa 2006/o7. Pretoria: Department of Labour.

DOL (Department of Labour). (2008). National skills development strategy: Implementation report. Pretoria: Department of Labour.

DPRU (Development Planning Research Unit). (2010). Income and non-income inequality in post- apartheid South Africa: What are the drivers and possible policy interventions. Cape Town: Development Planning Research Unit, University of Cape Town.

DSD (Department of Social Development). (2002). Transforming the present protecting the future: Report of the Committee of Inquiry into a comprehensive system of social security for South Africa. Pretoria: Government Printer.

Dube, O., Hausmann, R. \& Rodrik, D. (2007). South Africa: Identifying the binding constraint on shared growth. CID South Africa project, Harvard University.

Ferguson, J. (2009). The uses of neo-liberalism. Antipode, 41(S1), 166-184.

Gelb, S. (2003). Inequality in South Africa: Nature, causes and responses. Johannesburg: The EDGE Institute.

Gorz, A. (1973). Socialism and revolution. NewHaven: Anchor.

Grawitzky, R. (2007). SETAs - A vehicle for the skills revolution? An external report commissioned the Development Policy Research Unit (DPRU) of the University of Cape Town (UCT). Cape Town: UCT.

Groener, Z. (1997). Adult education and training in the South African transition (1990 to 1994). A study of policymaking. Unpublished PhD Dissertation.

Groener, Z. (2000). The political and economic contexts of adult education and training in South Africa. In S. A. Indabawa, A. Oduaran, T. Afrik, \& S. Walters (Eds.), The state of adult and continuing education in Africa (pp. 161-177). Windhoek: University of Namibia.

Hirsch, A. (2005). Season of hope. South Africa/Canada: University of Kwazulu-Natal Press/International Development Research Centre.

HRSDC/CMEC (Human Resources Development Canada/Council of Ministers of Education Canada) (1997). Survey of trends in adult education and training in Canada. Report of Canada in preparation for Convintea V, 1997. Accessed 15 January 2014 from http://publications.cmec.ca/ international/adulted-en.stm.

Kraak, A. (2004a). Training policies under late apartheid: The historical imprint of a low skills regime. In S. McGrath, A. Badroodien, A. Kraak, \& L. Unwin (Eds.), Shifting understandings of skills in South Africa: Overcoming the historical imprint of a low skills regime (pp. 46-70). Cape Town: Human Sciences Research Council Press. 
Kraak, A. (2004b). An overview of South African human resources development. Cape Town: HSRC Press.

Kraak, A. (2005). Human resources development and the skills crisis in South Africa: The need for a multi-pronged strategy. Journal of Education and Work, 18(3), 57-83.

Leite, P., McKinley, T. \& Osorio, R. (2006). The post-apartheid evolution of earnings inequality in South Africa 1995-2004. Brazil: United Nations Development Programme International Poverty Centre.

Leibrandt, M., et al. (2005). Measuring changes in South African inequality and poverty using 1996 and 2001 census data. Cape Town: University of Cape Town, Centre for Social Science Research.

Lowe, G. (2001). Learning in the 21st century: Key issues and questions. Background paper for the National Roundtable on Learning, March 2001, Edmonton, AB. Accessed 19 January 2014 from http://www.cprn.org/doc.cfm?doc=191\&l=en.

Magubane, Z. (2004). The revolution betrayed? Globalization, neo-liberalism, and the post-apartheid state. The South Atlantic Quarterly, 103(4), 657-671.

Marais, H. (1998). South Africa. Limits to change: The political economy of transition. London/New York/Cape Town: Zed Books/University of Cape Town.

Marais, H. (2001). South Africa: Limits to change: The political economy of transition. 2nd, rev. and expand new ed. London/Cape Town: Zed Books/University of Cape Town Press.

Marais, H. (2011). South Africa pushed to the limits: The political economy of change. Claremont: University of Cape Town Press.

Maserumule, M. (2011). Politics of transition in South Africa and the post-1994 democratic state. Journal of Asian and African Studies, 47(3), 301-314.

May, J. (Ed.). (2000). Poverty and inequality in South Africa: Meeting the challenge. London/New York: Zed Books.

Mayer, M., \& Altman, M. (2005). South Africa's economic development trajectory: implications for skills development. Journal of Education and Work, 18(1), 33-56.

Mbeki, T. (2003). Address by President Mbeki to the National Council of Provinces. $\begin{array}{lllll}\text { Accessed } & 19 & \text { January } & 2014 & \text { from }\end{array}$ http://www.e-tools.co.za/newsbrief/2003/news1112.txt.

McGrath, S. (2004). The shifting understandings of skills in South Africa since industrialisation. In S. McGrath, S., A. Badroodien, A. Kraak, and L. Unwin, L. (eds), Shifting understandings of skills in South Africa: Overcoming the historical imprint of a low regime (pp. 1-19). Cape Town: Human Sciences Research Council Press.

McGivney, V. (1999). Returning women: Their training and employment choices and needs. Leicester, UK: NIACE. (ERIC Document ED 429 205).

Mhone, G. (2000). Enclavity and constrained labour absorptive opacity in Southern African countries. ILO/SAMAT Policy Paper Series no. 12. Geneva: International Labour Organization (ILO).

Michie, J., \& Padayachee, V. (1997). The political economy of South Africa's transition. London: The Dryden Press. 
Millar, P. \& Falk, I. (2000). Seniors online: Online literacy and learning by senior citizens in rural centres. Australia: Adult Literacy and Numeracy Australian Research Consortium. (ERIC Reproduction Document. ED 457 399).

Myers, K. \& de Broucker, P. (2006). Too many left behind: Canada's Adult Education and Training System. Research Report W/34 Work Network.

Office of the President. (1994). White paper on reconstruction and development. Cape Town: South African Government Printers.

Office of the President. (1996). Growth, employment and redistribution: A macro-economic strategy. Cape Town: South African Government Printers.

Office of the President. (1997). Green paper skills development strategy for economic and employment growth in South Africa. Cape Town: South African Government Printers.

Office of the President. (1998a). Skills Development Act. Cape Town: South African Government Printers.

Office of the President. (1998b). Skills Levies Act. Cape Town: South African Government Printers.

Orkin, M. (1995). Living in South Africa. Selected findings of the 1995 October household survey. Pretoria: Central Statistics Service.

OECD (Organisation for Economic Co-operation and Development) (2002). Thematic review of adult learning: Canada. Background report. Paris: OECD. Summary available from http://www.oecd.org/ dataoecd/51/32/1940307.pdf.

Pilger, J. (1998). Hidden agendas. London: Vintage.

Potter, J., \& Ferguson, C. (2003). Canada's innovation strategy and lifelong learning: Facilitating adult learning in Canada. Fredericton, NB: University of New Brunswick, Department of Extension and Summer Session.

Przeworski, A. (1995). Sustainable democracy. Cambridge: Cambridge University Press.

Saul, J. (1992). Structural reform: a model for the revolutionary transformation of South Africa. Transformation, 20.

Saul, J. (2010). Is socialism still an alternative? Studies in Political Economy, 86, 167-185.

Saul, J. (2011). 'Structural reform' - the concept continues. Transformation, 75, 13-22.

Saul, J., \& Gelb, S. (1986). The crisis in South Africa. New York: Monthly Review Press.

Seekings, J. (2007). Poverty and inequality after apartheid. Cape Town: University of Cape Town, Centre for Social Science Research.

Seekings, J., Leibrandt, M., \& Nattrass, N. (2004). Income inequality after apartheid. Cape Town: University of Cape Town, Centre for Social Science Research.

Seekings, J., \& Nattrass, N. (2005). Class, race, and inequality in South Africa. New Haven: Yale University Press.

Statistics South Africa. (1995). Income and expenditure survey (IES). Pretoria: Statistics South Africa. 
Statistics South Africa (2007). Labour force survey. Historical Revision September Series 2000-2007. Statistical Release P0210. Pretoria: Statistics South Africa. Accessed $\quad 31 \quad$ December 2013 fromhttp://www. statssa.gov.za/publications/Po210/Po210September2000,2001,2002,2003,2004 ,2005,2006,2007.pdf.

Terreblanche, S. J. (2002). A history of inequality in South Africa, 1652-2002. Pietermaritzburg: University of Natal Press.

UNDP (United Nations Development Programme) (2003). South Africa human development report 2003. The challengeof sustainable development in South Africa: Unlocking people's creativity. New York/ Oxford: Oxford University Press. Accessed 24 November 2013 from http://hdr.undp.org/en/reports/ nationalreports/africa/southafrica/south_africa_2003_en.pdf.

U.S. Department of Education (1998). Adult education participation decisions and barriers: Review of conceptual frameworks and empirical studies (Working Paper No. 98-10). Washington, DC: National Center for Education Statistics, Office of Educational Research and Improvement.

Webster, E., \& Adler, G. (1999). Toward a class compromise in South Africa's "double transition": Bargained liberalisation and the consolidation of democracy. Politics \& Society, 27, 347-385.

Wolpe, H. (1988). Race, class \& the apartheid state. London: Currey.

\section{The author}

Zelda Groener graduated with a $\mathrm{PhD}$ as a Fulbright scholar, specialising in Comparative and International Education, from the University of California at Los Angeles in 1997. She is an Associate Professor at the University of the Western Cape (UWC), South Africa, where she held the position of Director of the Centre for Adult and Continuing Education during 2001-2013. Her research interests focus on adult education and social transformation; and on national and international adult education policies. A recent research grant from the National Research Foundation (NRF) in South Africa afforded her a more specific research focus on education and inequality. 